Fissile Materials Disposition Program

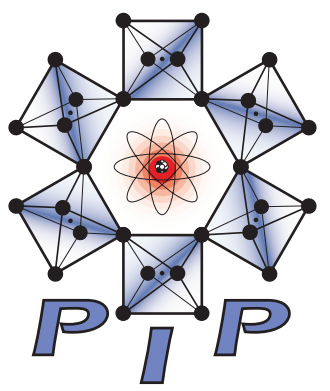

\title{
Rough Order of Magnitude Cost Estimate for Immobilization of 18.2 MT of Plutonium Sharing Existing Facilities at Hanford with Pit Disassembly and Conversion Facility
}

Alternative 2

Prepared by Bechtel for

Law rence Livermore National Laboratory

June 1998

Plutonium Immobilization Project

Law rence Livermore National Laboratory

Livermore, California 94550 


\section{DISCLAIMER}

This document was prepared as an account of work sponsored by an agency of the United States Government. Neither the United States Government nor the University of California nor any of their employees, makes any warranty, express or implied, or assumes any legal liability or responsibility for the accuracy, completeness, or usefulness of any information, apparatus, product, or process disclosed, or represents that its use would not infringe privately owned rights. Reference herein to any specific commercial product, process, or service by trade name, trademark, manufacturer, or otherwise, does not necessarily constitute or imply its endorsement, recommendation, or favoring by the United States Government or the University of California. The views and opinions of authors expressed herein do not necessarily state or reflect those of the United States Government or the University of California, and shall not be used for advertising or product endorsement purposes.

This report has been reproduced directly from the best available copy.

Available to DOE and DOE contractors from the Office of Scientific and Technical Information P.O. Box 62, Oak Ridge, TN 37831

Prices available from (423) 576-8401

Available to the public from the National Technical Information Service

U.S. Department of Commerce 5285 Port Royal Rd. Springfield, VA 22161

Work performed under the auspices of the U.S. Department of Energy by Lawrence Livermore National Laboratory under Contract W-7405-ENG-48. 
Rough Order of Magnitude Cost Estimate for

Immobilization of 18.2 MT of Plutonium Sharing Existing Facilities at Hanford with Pit Disassembly and Conversion Facility

\author{
Alternative 2 \\ Prepared by Bechtel \\ for \\ Lawrence Livermore National Laboratory \\ June 1998
}


UCRL-ID-131066 


\section{Table of Contents}

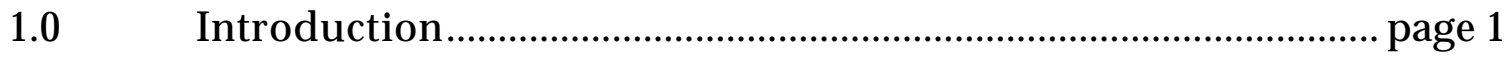

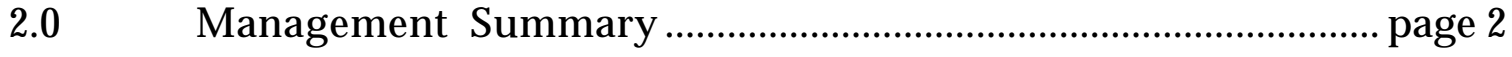

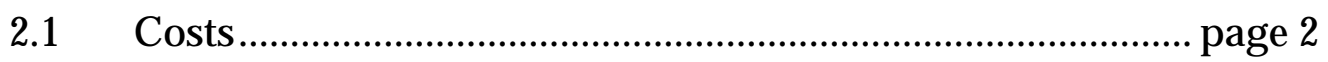

3.0 Assumptions and Exclusions .................................................... page 6

3.1 Assumptions..................................................................... page 6

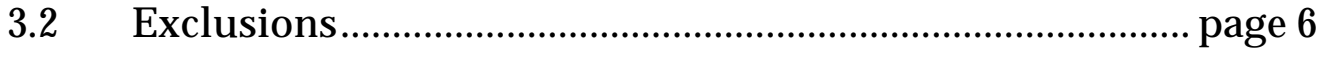

4.0 Cost Estimates............................................................................ page 7

4.1 Technology Development ................................................. page 7

4.2 Process Equipment............................................................. page 7

4.3 Process Facilities ................................................................ page 8

4.4 Site Improvements and Support Facilities .......................page 10

4.5 Regulatory Compliance ....................................................... page 11

4.6 Operations and Maintenance ............................................... page 11

4.7 Decontamination and Decommissioning........................ page 12

Appendix A Assumptions and Estimate Basis ........................................ page 13 
UCRL-ID-131066 


\subsection{Introduction}

The purpose of this Cost Estimate Report is to identify preliminary capital and operating costs for a facility to immobilize 18.2 metric tons (nominal) of plutonium as a ceramic in an existing facility at Hanford, the Fuels and Materials Examination Facility (FMEF). The Pit Disassembly and Conversion Facility (PDCF), which is being costed in a separate report will also be located in the FMEF in this co-location option.

The technical engineering data used as the basis for this study is presented in the EIS Data Call Input Report, "Plutonium Immobilization Plant Using Ceramic in Existing Facilities at Hanford." The FMEF will require minimal facility modifications to accommodate the Plutonium Immobilization Plant (PIP). Adequate space is available within the FMEF for installation of the immobilization process equipment. Facility HVAC, utility, and support systems exist to support the immobilization operations. Building modifications are primarily the removal of the SAF line (gloveboxes and support equipment) on the 70' level and building interior changes.

The plutonium immobilization equipment will primarily occupy the $42^{\prime}$ and 70' levels of the FMEF, with the same equipment layout as in the sole occupancy case. The Pit Disassembly and Conversion Facility would occupy the $21^{\prime}$ and 0 ' (Entry) levels. Elements of the FMEF and adjacent Fuel Assembly Area (FAA) that will be shared by PIP and PDCF include shipping and receiving, laboratory, waste handling, security, offices, maintenance shops, SNM storage vault, and utilities. It was assumed that the existing utilities and support systems are adequate or only need minor upgrades to support both the PIP and PDCF. The PIP cost estimate was reconciled with the PDCF cost estimate to confirm the use and costs of shared systems and personnel.

The facility design for a 50 metric ton plutonium throughput plant will be used for the 18.2 metric ton facility. Plutonium conversion operations will operate at the same design rate as the 50 metric ton facility over the 10 year operating period. Some of the process equipment will operate for a shorter period of time and fewer operators will be required. The assumptions, missions, design bases, facility and process descriptions, and accident analyses are the same. Therefore it is assumed that the capital cost for the 18.2 metric ton facility is identical to that of the 50 metric ton facility. However, the following operating costs will be less: consumable materials, equipment replacement and maintenance labor, employment requirements, and waste generation. 
The Plutonium Immobilization Plant will process 1.8 metric tons of plutonium materials per year. Plutonium from DOE sites is received and processed (physically and chemically) into an oxide form in the plutonium conversion portion of the plant. In the first stage immobilization process, the plutonium oxide is then incorporated into ceramic form by blending and weighing with ceramic precursor, binder and water. The mixture is dried, pressed into discs (pucks), sintered in a furnace, cooled, inspected and loaded into cans. The filled cans are then mounted on a rack inside a defense high level waste (HLW) canister. The canister will be transferred by truck to the planned Hanford waste vitrification plant to undergo a second stage immobilization, which fills the canister with radioactive HLW glass. A total of 17.3 metric tons of plutonium ceramic discs in 1,900 cans, loaded into 68 HLW canisters will be produced annually. The plant is operated for 10 years to process the entire 18.2 metric tons of plutonium metal and oxide to be immobilized.

The estimates were developed from preconceptual engineering data developed for the Environmental Impact Statement (EIS) Data Call Input Report and site visits, and utilized historical cost data from similar nuclear and industrial projects, as well as budget-level cost quotations where available. It should be noted that the estimates developed in this and subsequent reports for other alternatives are intended to provide a basis for comparison of significant cost differences between the alternatives and are not intended to yield project budget costs. Exceptions and/or additions to these assumptions and exclusions are noted. Accordingly, reconciliation between this estimate and previous estimates for similar options is inappropriate.

\subsection{Management Summary}

\subsection{Costs}

The cost analysis including capital, operating and maintenance, and decontamination and decommissioning costs for the Plutonium Immobilization Plant sharing an existing facility (FMEF) at Hanford with Pit Disassembly and Conversion Facility are presented in this report. These costs are summarized in Table 1. 
Table 1 Cost Summary

Plutonium Immobilization Plant Sharing Existing Facilities at Hanford with Pit Disassembly and Conversion Facility

\begin{tabular}{||c|c|c||}
\hline Section & CATEGORY & $\begin{array}{c}\text { Cost-(\$M) } \\
\mathbf{9 7} \mathbf{\$}\end{array}$ \\
\hline 4.1 & Technology Development & excluded \\
\hline 4.2 & Process Equipment & 246 \\
\hline 4.3 & Process Facilities & 89 \\
\hline 4.4 & Site Improvement and Support Facilities & 8 \\
\hline 4.5 & Regulatory Compliance & excluded \\
\hline & Total Phase I Facility Capital Costs & $\mathbf{3 4 3}$ \\
\hline 4.6 & Operations and Maintenance (10 years) & 322 \\
\hline 4.7 & Decontamination \& Decommissioning & 35 \\
\hline & Total Costs & $\mathbf{7 0 0}$ \\
\hline
\end{tabular}

The costs are presented in millions of fourth quarter 1997 dollars. The costs reflect a contingency of $40 \%$ for Process Equipment, Process Facility, and Site Improvement and Support Facilities, and no contingency for Operation and Maintenance.

Facility capital costs include engineering, construction, equipment fabrication, initial spare parts, installation, certification and testing, and project management. The total costs do not include costs for technology development and regulatory compliance. The estimates of these costs will be covered in separate cost estimate reports. Also, costs for site qualification, site selection, oversight/ownership, fees, royalties, payments-in-lieu-of-taxes, and cost of capital are not included. Transportation costs are not included.

Costs for Process Equipment include estimates for major process equipment as shown in the equipment list for this option. Note the equipment list is based on the EIS Data Call Input Report and layouts. These costs were developed based on informal vendor quotes (where available), previous estimates for similar equipment, current estimating manuals, or estimates based on equipment weights, materials of construction and transportation to the site. 


\begin{tabular}{||c|c|c||}
\hline Section & CATEGORY & Cost-(\$M) '97 \$ \\
\hline $\mathbf{4 . 2}$ & Process Equipment & Total \\
\hline 4.2 .1 & Engineering & 51 \\
\hline 4.2 .2 & Fabrication & 90 \\
\hline 4.2 .3 & Installation & 90 \\
\hline 4.2 .4 & Certification and Test & 10 \\
\hline 4.2 .5 & Project Management & $\mathbf{2 4 6}$ \\
\hline \multicolumn{2}{|c|}{} \\
\hline
\end{tabular}

Cost for Process Facilities includes costs for structural modifications to the FMEF. These modifications are primarily the demolition and removal of the SAF line on the 70 ' level. This includes disassembly and removal of gloveboxes, support equipment, piping, ducts, conduit, and interior partition walls. No radioactive materials have been introduced into the FMEF, thus decontamination is not required. Other structural modifications include installing a doorway and openings in the Decon Cell and installing a material conveyor between the $42^{\prime}$ and $70^{\prime}$ levels. A mezzanine is constructed in the Upper Process Cell on the $42^{\prime}$ level and interior partition walls are constructed throughout.

These costs are based on preliminary estimates of building structural materials (e.g., concrete, rebar, etc.) and estimates of facility support equipment (such as building heating, ventilating and air conditioning; fire protection, electrical motor control centers, etc.). Pricing of these materials and systems was developed from historical data from previous estimates for similar equipment in similar service, from current estimating manuals, or by the use of historical factors developed for similar nuclear / industrial projects.

\begin{tabular}{||c|c|c|}
\hline \hline Section & CATEGORY & Cost-(\$M) ‘97 \$ \\
\hline $\mathbf{4 . 3}$ & Process Facilities & Total \\
\hline 4.3 .1 & Engineering & 19 \\
\hline 4.3 .2 & Construction & 65 \\
\hline 4.3 .3 & Project Management & 5 \\
\hline & Total & $\mathbf{8 9}$ \\
\hline $\mathbf{4 . 3}$ & \multicolumn{2}{|c|}{} \\
\hline
\end{tabular}


The FMEF is an existing facility. Support systems such as HVAC (glovebox and building), utilities (compressed air, water, cooling water, etc.), and electrical power are existing and assumed to be adequate to support the PIP. Site Improvement and Support Facilities are existing.

Costs for site improvements and plant utilities and services include the addition of a new 4.32 acre laydown area, and an allowance for the inspection, repair, and upgrade as necessary of existing systems. All other support facilities are existing.

\begin{tabular}{||c|c|c||}
\hline Section & CATEGORY & Cost-(\$M) '97 \$ \\
\hline $\mathbf{4 . 4}$ & $\begin{array}{c}\text { Site Improvement and Support } \\
\text { Facilities }\end{array}$ & Total \\
\hline 4.4 .1 & Engineering & 1.5 \\
\hline 4.4 .2 & Construction & 6.0 \\
\hline 4.4 .3 & Project Management & 0.5 \\
\hline & & $\mathbf{8 . 0}$ \\
\hline $\mathbf{4 . 4}$ & Total & \\
\hline
\end{tabular}

Operations and maintenance costs include labor, materials, utility and waste management and disposal costs necessary to operate the facility at design capacity for 10 years. Facility start-up cost is factored at $120 \%$ of the annual operation and maintenance labor cost.

\begin{tabular}{||c|c|c||}
\hline Section & CATEGORY & Cost/yr.-(\$M) '97 \$ \\
\hline $\mathbf{4 . 6}$ & Operation and Maintenance & Total \\
\hline 4.6 .1 & All consumable materials & 5 \\
\hline 4.6 .2 & Utilities & 1 \\
\hline 4.6 .3 & Labor & 21 \\
\hline 4.6 .4 & Waste Management and Disposal & 3 \\
\hline & Total cost per year & $\mathbf{3 0}$ \\
\hline $\mathbf{4 . 6}$ & Facility Start-up & 25 \\
\hline \multicolumn{2}{|c|}{ Total for 10 years } \\
\hline
\end{tabular}


Decontamination and decommissioning (D\&D) costs are based on the assumption that a DOE M\&O contractor or A/E will shut down, decontaminate, and remove contaminated or other surplus equipment from the facility. The cost of D\&D is assumed to be $10 \%$ of the facility capital cost for a similar facility (i.e., PIP in new construction at SRS), with an adjustment for the FMEF building size.

\begin{tabular}{|c|c|c||}
\hline Section & CATEGORY & Cost-(\$M) 99 \$ \\
\hline 4.7 & $\begin{array}{c}\text { Decontamination \& } \\
\text { Decommissioning }\end{array}$ & 35 \\
\hline
\end{tabular}

\subsection{Assumptions and Exclusions}

\subsection{Assumptions}

Major design assumptions are based on the technical engineering data developed during 1997 and used as the basis for the EIS Data Call Input Report. Capital cost equipment and facilities are therefore based on preliminary layout drawings found in the EIS Data Call Report and the equipment list developed for the EIS design. Operating costs are based on data tables in the EIS report. A number of cost estimate factors, for parametric analysis, were developed from meetings held between DOE, Lawrence Livermore National Laboratory, Fluor Daniel, Burns and Roe, and Bechtel.

\subsection{Exclusions}

The following major items have been excluded from the estimates:

- Cost of land

- R\&D / technical development costs

- NEPA, licensing and permitting costs

- DNFSB / DOE oversight costs

- Revenues

- Transportation costs

- Escalation beyond the fourth quarter of FY 1997 
- Regulatory compliance documentation

- M\&O fees

- Payments-in-lieu-of-taxes to local communities

- Government fees to privately owned facilities

- Transportation or storage of plutonium forms and wastes out of facility (off-site)

- Existing FMEF and planned Hanford HLW vitrification plant

- Existing support and service facilities

- Waste management facilities

\subsection{Cost Estimates}

Cost estimates have been developed for Capital, O\&M and D\&D cost components.

\subsection{Technology Development}

The costs for research and development to support the Plutonium Immobilization Plant are not included in the scope of this cost estimate report. Estimates of costs to complete the research and development necessary before detailed design and engineering will be covered in a separate report.

\subsection{Process Equipment}

The process equipment cost estimate provides costs for the major process equipment as listed in the equipment list developed for the Plutonium Immobilization Plant using ceramic in existing facilities at Hanford. It also includes costs for process piping and instrumentation. Costs are based on vendor quotes (where available), historical costs of similar equipment in similar service, current estimating/pricing manuals or estimated costs per pound of equipment of the same complexity and materials of construction.

Factors are included for process equipment initial spares, distributable field costs, contractors bond, overhead and profit, construction and project management. 


\subsubsection{Engineering}

An allowance of $25 \%$ of the total field costs for Architect/Engineering Title I and II design, engineering, and procurement support cost are included in this estimate. An additional 15\% of Title I and II engineering cost is also included for Title III engineering and field verification.

\subsubsection{Fabrication}

Costs for fabrication includes costs for shop or field fabrication of process equipment, piping, or instrumentation.

\subsubsection{Installation}

Costs for the installation include the costs associated with field installation of process equipment utilizing the manual labor rates for Washington issued by Burns and Roe and a standard 40 hour work week. A performance loss factor was applied for installation in FMEF caused by congestion from PDCF construction activities.

\subsubsection{Certification and Test}

Costs for certification and test of process equipment are based on an allowance of $5 \%$ applied to the fabrication cost.

\subsubsection{Project Management}

Project management costs for the process equipment include all required project supervision and field management. It is assumed that the DOE will hire an Architect-Engineer (A/E) construction program manager to interact with the design $\mathrm{A} / \mathrm{E}^{\prime} \mathrm{s}$, equipment vendors, and the construction contractor.

\subsection{Process Facilities}

The Process Facilities estimate includes all costs for the modifications to the FMEF and FAA. The cost of the HLW vitrification plant is not included.

The following subsections describe the major cost estimating assumptions and estimating bases: 


\subsubsection{Engineering}

An allowance of $25 \%$ of the total field costs for Architect/Engineering Title I and II design, engineering, and procurement support cost are included in this estimate. An additional 15\% of Title I and II engineering cost is also included for Title III engineering and field verification.

\subsubsection{Construction}

Construction costs for process facilities includes the costs associated with field installation of all bulk construction materials and support equipment associated with the process facility building utilizing manual labor rates for Washington issued by Burns and Roe, and a standard 40 hour work week. A performance loss factor has been applied based on congestion caused by PDCF construction activities. For demolition activities in FMEF, a factor based on indoor location (limited access) was also applied.

\subsubsection{Project Management}

Project management costs for the process facilities include all required project supervision and field management. It is assumed that the DOE will hire an A/E construction program manager to interact with the design $\mathrm{A} / \mathrm{E}$ 's, equipment vendors, and the construction contractor.

The major assumptions and cost estimate bases for the process facility are:

\subsubsection{Process Building}

Modifications to the existing FMEF include demolition and removal of interior concrete and metal stud partition walls, disassembly and removal of existing gloveboxes and equipment, construction of new interior concrete and partition walls, and new openings in existing walls and floor slab.

Other Process Building material quantities including electrical components, instrumentation, lighting, etc. are quantified using preliminary takeoffs from the EIS Data Call Input Report for Plutonium Immobilization Plant in Existing Facilities at Hanford.

Costs for new support equipment and systems needed for the facility are based on the support equipment list priced using previous estimates for similar equipment or systems as a guide, current 
estimating manuals, or estimated costs based on equipment weights and materials of construction.

\subsection{Site Improvement and Support Facilities}

Costs for site improvements and plant utilities and services include a 4.32 acre laydown area. An allowance for inspection and minor repair or upgrade as necessary of existing systems is included. All other support facilities are existing.

The following support buildings are existing: administration building, fire and medical station, cooling tower, entry control building, and sanitary and industrial waste treatment facilities.

Assumptions and estimate bases for site improvements and utilities are covered in Appendix A of this report.

\subsubsection{Engineering}

An allowance of $25 \%$ of the total field costs for Architect/Engineering Title I and II design, engineering, and procurement support cost are included in this estimate. An additional 15\% of Title I and II engineering cost is also included for Title III engineering and field verification.

\subsubsection{Construction}

Construction costs for the site improvement and support facilities includes the costs associated with field labor, installation of all bulk construction materials and support equipment associated with each site improvement, utility, service or support facility building utilizing manual labor rates for Washington provided by Burns and Roe and a standard 40 hour work week.

\subsubsection{Project Management}

Project management costs for the process facilities includes all required project supervision and field management. It is assumed that the DOE will hire an $\mathrm{A} / \mathrm{E}$ construction program manager to interact with the design $A / E$ 's, equipment vendors, and the construction contractor. 


\subsection{Regulatory Compliance}

Permits, licensing and environmental documentation are not included in the scope of this cost estimate. Estimates of the costs of permits, licensing, and environmental documentation are covered in a separate cost estimation report.

\subsection{Operations and Maintenance}

The operations and maintenance (O\&M) cost estimate for the Plutonium Immobilization Plant includes total annual costs for operating personnel wages, utilities, consumable, operation material and maintenance expenditures, and waste disposal. Total operations and maintenance estimates are based on immobilization of plutonium over a 10 year period.

\subsubsection{Materials}

Cost of consumable materials for process operations such as chemicals, ceramic precursor, binder and lubricant are based on costs found in "Chemical Marketing Prices Report" magazine. For additional cooling tower water system treatment chemicals, the cost estimate is based on a Nalco Chemical Company preliminary quotation. Cost for uranium dioxide (UO2) is based on a quoted price of $\$ 53 / \mathrm{kg}$ from Cameco Corp. (Canada). Cost of product cans and canisters are based on pricing from Savannah River Site (DWPF). Operating material costs for $500 \mathrm{cu} \mathrm{ft}$ waste container boxes and 55-gallon drums are based on packaging costs from Burns and Roe. The cost for facilities and equipment maintenance is based on an allowance of $1 / 2 \%$ of the total equipment capital cost plus $1 \%$ of the total facility operation and maintenance labor cost. The cost for major capital replacement is based on an allowance of $1 \%$ of facility equipment capital cost (excluding demolition costs).

\subsubsection{Utilities}

The cost for utilities and services, including materials, safety, environmental and security, are based on the current electricity, water usage, and telephone service cost at Hanford.

\subsubsection{Labor}

Operations cost for personnel is based on the facility operating manpower requirements described in the Plutonium Immobilization 
Plant Using Ceramic EIS Data Call Input Report. The rate for nonmanual labor employee including updated burden rates are based on DOE wage rate for Washington. Wages for manual labor employee including updated fringe benefits are based on wage rates for Washington issued by Burns and Roe.

\subsubsection{Waste Management and Disposal}

Waste management and disposal costs are estimated based on waste disposal cost information supplied by Burns and Roe for treatment and disposal of transuranic waste. Disposal costs for hazardous, mixed and low level radwaste were based on information from Hanford.

\subsection{Decontamination and Decommissioning}

Decontamination and decommissioning (D\&D) costs are based on the assumption that a DOE M\&O contractor or $\mathrm{A} / \mathrm{E}$ will shutdown, decontaminate, and remove contaminated and surplus equipment from the facility. The cost of D\&D is assumed to be $10 \%$ of the facility capital cost for a similar facility (i.e., PIP in new construction at SRS), with an adjustment for the FMEF building size. 


\title{
Appendix A - Assumptions and Estimate Bases
}

\section{A-1 Assumptions}

\author{
Client Lawrence Livermore National Laboratory \\ Project 400-Area, Hanford Site, Washington
}

Location

Project The project consists of the comparison of capital and O\&M costs Scope for several facility options for plutonium immobilization.

Scope of Design, procurement, construction and operating costs for a Option Plutonium Immobilization Plant sharing an existing facility (FMEF) located at Hanford with Pit Disassembly and Conversion Facility

Type of Order of magnitude capital cost estimates

\section{Estimate}

Purpose of Compare the costs of several facility options and locations of the Estimate process plants for plutonium immobilization.

Pricing Costs are at 4th quarter, 1997. Escalation is excluded.

Level

Project Estimate assumes a "normal" schedule without scheduled

Schedule overtime. However, in areas of restriction and modifications, multiple shifts of working schedule will be applied as required. 


\section{A-2 Existing Construction Estimate Bases}

\section{Capital Costs Estimate}

\section{Scope Definition}

Scope of the work is based on site visits, drawings, sketches, flow diagrams and equipment lists presented in the EIS Data Call Input Report, Plutonium Immobilization Plant Using Ceramic in Existing Facilities at Hanford.

- Modifications to the existing FMEF Building were based on six FMEF layout plans, one FAA layout plan, and four marked-up drawings of FMEF for demolition.

- Process equipment was defined by the equipment list, EIS Data Call Report, layouts sketches, flow diagrams, and Hanford Site support.

- Mechanical/HVAC were defined by a newly developed flow diagram, equipment list and layout sketches.

- Electrical/Instrument Control were based on newly developed single line diagram and equipment list.

\section{Site Improvement \& Utilities}

The following were made as the bases of the cost estimate for site improvements and utilities:

- The site consists of a modified FMEF. The majority of the process equipment is installed on the $42^{\prime}$ and $70^{\prime}$ levels of FMEF.

- A new 4.32 acre laydown area is provided for construction of PIP.

\section{Yard piping}

This system is existing. Minimal allowance was provided for small modifications or improvements. 


\section{Yard electrical}

This system is existing. Minimal allowance was provided for small modifications or improvements.

\section{Pricing}

\section{Equipment Pricing:}

Equipment was priced based on the description, capacity or size in the equipment list, with reference to previous estimates for similar facilities, inhouse historical data bases, and current published information as available.

Glove Box Pricing:

All glove boxes are constructed of stainless steel, double-wall (water-wall) and lined with $1 / 4^{\prime \prime}$ lead on all sides, top and bottom, and include a support stand. The number of windows, glove ports, and electrical/utility penetrations were estimated for each glove box.

The glove boxes are fabricated at the vendor's shop and shipped to the site. The glove boxes will be delivered to a staging area, where equipment and controls will be installed in the glove boxes. The fitted glove boxes will be moved to the installation location in FMEF, installed and tested.

Bulk Materials Pricing:

Bulk materials were priced based on current estimating experience or recent publications of cost data such as Means and Richardson's estimating manuals.

\section{Labor}

Wages for manual labor employee including updated fringe benefits are based on wage rates for Washington issued by Burns and Roe.

Performance Factors:

The following adjustment factors were applied to the work performed inside the FMEF building:

Location Factor (1.18) - Increase is due to the work performed located inside FMEF. This factor was only applied to the demolition work estimate. 
Congestion Factor (1.20) - Increase is due to interference with Pit Disassembly and Conversion Facility construction activities at the same site.

\section{Washington State Sales Tax}

Washington State Sales Tax of $8 \%$ is included in material costs.

\section{Distributable (General Conditions), Overhead and Profit Costs}

Distributable costs, which include the temporary construction facilities, construction equipment, tools, personnel, field office costs and other distributable support costs, are included to cover the distributable material costs, support and non-manual labor costs, contractor's overhead and profit.

\section{Business and Occupational Tax}

A tax rate of $0.471 \%$ is applied to equipment, materials, labor and subcontract costs.

\section{Contractor's Bond}

Contractor's bond is included.

\section{Construction Management}

Construction management costs, including the construction manager's overhead and profit was included.

\section{Engineering and Other Design Services}

Engineering and other design services costs include functions such as project control, engineering, documentation, quality control, procurement, and support services. These costs were factored at $25 \%$ of the field costs.

\section{Project Management}

Project management costs are included. 


\section{Escalation}

Escalation is excluded. Costs are at fourth quarter 1997 level.

\section{Contingency}

Contingency is included as follows:

Existing Facility $\quad 40 \%$

\section{Exclusions}

The following major items have been excluded from the estimates:

- Cost of land

- R\&D / technical development costs

- NEPA, licensing and permitting costs

- DNFSB / DOE oversight costs

- Revenues

- Transportation costs

- Escalation beyond the fourth quarter of FY 1997

- Regulatory compliance documentation

- M\&O fees

- Payments-in-lieu-of-taxes to local communities

- Government fees to privately-owned facilities

- Transportation or storage of plutonium forms and wastes out of facility (off-site)

- Existing FMEF building and planned HLW vitrification plant

- Existing support and service facilities

- Waste management facilities 
